\title{
NEW AND EMERGING ISSUES ARISING OUT OF THE BANKRUPTCY OR INSOLVENCY OF ENERGY COMPANIES: THE IMPACT OF THE LATEST RECESSION
}

\author{
Josef G.A. KRÜGER, Q.C. AND R.J. DANIEL GILBORN*
}

This article highlights new and emerging bankruptcy and insolvency issues that arose out of the latest recessionary period, which led or contributed to the insolvencies of several global energy companies. Through an analysis of a sample of decisions arising out these proceedings, the article posits that the potential exists for further arguments regarding priority disputes, distributions, and set-off in future insolvencies involving energy companies.

\begin{abstract}
Cet article aborde les questions nouvelles et émergentes relatives aux cas de faillite et d'insolvabilité découlant de la dernière récession ayant abouti à l'insolvabilité de plusieurs sociétés d'énergie mondiales ou y ayant contribué. En analysant quelques décisions découlant de ces poursuites, l'article pose comme postulat qu'il serait possible de faire valoir d'autres arguments au sujet conflits privilégiés, de distributions et de déclencher des cas futurs d'insolvabilité de sociétés d'énergie.
\end{abstract}

\section{TABLE OF CONTENTS}

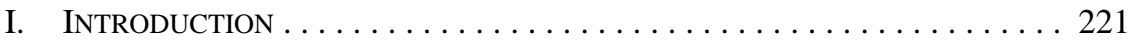

II. ATTEMPTS TO SECURE PRIORITY IN THE

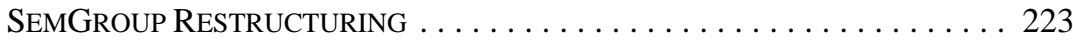

A. RE SEMCANADA CRUDE CO.: INTERIM DISTRIBUTION HEARING . . . 223

B. CELTIC V. SEMCANADA . . . . . . . . . . . . . . . . . . . . . . . . 229

III. DifFICULTIES IN ESTABLISHING SET-OFF IN THE

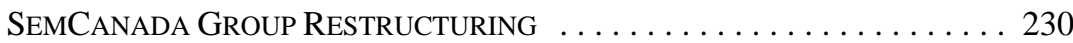

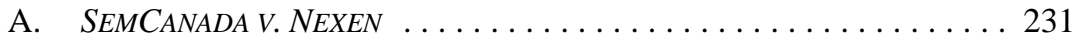

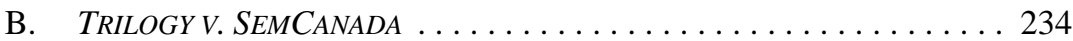

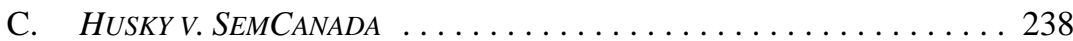

IV. THE USE OF A RECEIVER IN THE

CANADIAN SUPERIOR ENERGY INC. RESTRUCTURING . . . . . . . . . . . . 241

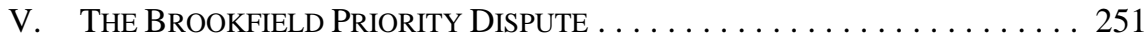

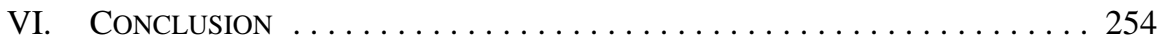

\section{INTRODUCTION}

The global recession that commenced in 2008 is one of the worst in recent history. It wreaked havoc on the global economy. The energy industry did not escape unscathed. Commodity prices slumped, demand for products produced by the energy industry shrank, funding for projects evaporated, and expense budgets were slashed. There were inevitable casualties among energy companies, both internationally and in Canada.

Looking back at the turmoil experienced by the global economy, one is surprised at the relatively low number of energy companies in Canada, and in Alberta in particular, that were

Josef Krüger is a Partner and Daniel Gilborn is an Associate, both at Borden Ladner Gervais, LLP. This is a revised version of the paper that was presented to the Canadian Energy Law Foundation Conference at Jasper Park Lodge on 24 June 2010. The authors wish to thank Peter Newman, a Borden Ladner Gervais, LLP Summer Student for 2010 and future articling student for 2011-2012 for his assistance in both preparing the final version of this article and creating the Powerpoint presentation for the Conference. 
forced into formal insolvency proceedings. Although this can partly be ascribed to the resilient way in which the Canadian economy, in general, managed to weather the latest recession, other factors played a major role. Pervasive low gas prices made it extremely difficult to sell distressed gas assets, compounding the losses of creditors in some insolvent estates. The general lack of available financing severely inhibited purchases of distressed assets. Finding interim financing to keep insolvent companies afloat during restructuring became a significant challenge. As a result, secured creditors became more inclined to enter into forbearance agreements with insolvent debtors. Some insolvent companies turned to informal restructurings and mergers in an attempt to avoid bankruptcy. All of these factors contributed to a situation where, instead of a wave of formal insolvency filings, Canada experienced only a few significant insolvencies among energy companies.

The impact of the latest recession nevertheless resulted in some new and emerging issues arising from the insolvency of energy companies.

First, the devastating consequences to oil and gas producers impacted by the SemGroup L.P. (SemGroup) insolvency proceedings gave rise to novel attempts by producers to prevent distributions to SemGroup's major senior secured creditors, or to secure a priority position ahead of those creditors.

Second, the plight of the creditors of insolvent corporations placed a renewed focus on the rights of set-off. In the SemGroup proceedings, the Alberta Courts handed down decisions that underscore the importance of contractual rights of set-off and the difficulties involved in applying equitable set-off where the debtor is not the insolvent debtor itself, but a related entity. Yet another SemGroup decision prevented a producer from applying set-off against amounts that it owed to the insolvent debtor where such funds were owed by the insolvent debtor in its capacity as operator and not to the insolvent debtor in its personal capacity. These decisions impact all oil and gas producers, as well as operators.

Third, the novel use of a receivership in the Canadian Superior Energy Inc. (CSEI) restructuring to protect the interest of a joint venture partner in a single offshore oil and gas asset was not without controversy. The appointment of the receiver, despite the protection provided to the joint venture partner in the Joint Operating Agreement (JOA), was strongly opposed by CSEI, and questioned by many. CSEI's subsequent filing for protection under the Companies' Creditors Arrangement Act ${ }^{1}$ resulted in dual track insolvency processes rife with the potential for conflict and failure. The situation was complicated by the involvement of Challenger Energy Corp. (CEC), an insolvent corporation related to CSEI, and required a complex restructuring plan that presented some unique challenges but nevertheless saw all creditors, including unsecured creditors, fully paid.

Fourth, in Brookfield Bridge Lending Fund v. Karl Oil and Gas Ltd., ${ }^{2}$ the Alberta Court of Appeal had to decide a priority conflict between a working interest owner in oil and gas assets and an operator's secured lender. The working interest owner was successful in the Court of first instance, which held that there was a constructive trust in favour of the working 
interest owner that trumped the operator's secured lender. ${ }^{3}$ The Court of Appeal was then called upon to decide the correctness of that decision, which had caused considerable consternation among banks and other lenders.

In this article, the authors critically review the above new and emerging issues, and comment on the impact thereof on energy companies in general.

\section{AtTempts to Secure Priority IN THE SEMGROUP RESTRUCTURING}

Before the global recession, beginning in the summer of 2008, SemGroup consisted of a group of United States based oil and gas investment companies, which had several Canadian affiliates and subsidiaries who were engaged in the marketing, sale, and co-ownership of oil and gas properties. SemGroup and its subsidiaries and affiliates based in the U.S. filed for Chapter 11 protection under the U.S. Bankruptcy Code 4 on 22 July 2008. SemGroup and its affiliates and subsidiaries had lost billions, much of it owing to the "short-selling" of oil stocks (also dubbed “wrong-way trading”) during the period where oil prices were escalating rapidly. ${ }^{5}$

As SemGroup's U.S. affiliates and subsidiaries fared, so did its Canadian relatives. Consequently, SemGroup's Canadian affiliates and subsidiaries (a group comprised of SemCanada Crude Company, SemCAMS ULC, SemCanada Energy Company, A.E. Sharp Ltd., CEG Energy Options Inc., 3191278 Nova Scotia Company, and 1380331 Alberta ULC (the SemCanada Group)) were all subject to various insolvency proceedings in the summer of 2008. The Alberta Court of Queen's Bench ordered all such proceedings consolidated under one CCAA proceeding for the entire SemCanada Group on 30 July $2008 .{ }^{6}$

SemGroup - along with many of SemCanada Group, as either direct parties or guarantors - had granted security to a group of syndicated lenders in the U.S., of whom the Bank of America was the administrator (the secured lenders) in consideration for various credit facilities (the loans). At the time of the initial insolvency event, the amount owed under the loans was some US\$2.5 billion. ${ }^{7}$ Additional secured and senior debt totalled approximately US\$3.3 billion. ${ }^{8}$

\section{A. RE SEMCANADA CRUDE CO.: INTERIM DISTRIBUTION HEARING}

One of the contested issues in the CCAA proceedings was the application by three of the SemCanada Group, all of whom were guarantors of the loans, to make an interim distribution to the secured lenders of some US\$90 million, which was the lion's share of the $\$ 113$ million

3 Brookfield Bridge Lending Fund v. Vanquish Oil \& Gas, 2008 ABQB 444, 96 Alta. L.R. (4th) 329 [Brookfield (Q.B.)].

11 U.S.C. 101.

Full details of the SemGroup downfall can be found in an article by Christopher Helman, "Inside the Semgroup Bust” Forbes (28 July 2008), online: Forbes.com <http://www.forbes.com/2008/07/28/ semgroup-oil-kivisto-biz-energy-cz_ch_0728semgroup.html>.

$6 \quad$ Re SemCanada Crude, 2009 ABQB 490, 57 C.B.R. (5th) 205 at paras. 2-6. See also Re SemCanada Crude, 2009 ABQB 252, 459 A.R. 112 at para. 2 [SemCanada v. Nexen]. Borden Ladner Gervais, LLP acted as counsel to the monitor, Ernst \& Young Inc., in the SemCanada Group CCAA proceedings.

7 Re SemCanada Crude, 2009 ABQB 90, 52 C.B.R. (5th) 131 at paras. 6-7 [SemCanada]. Ibid. at para. 24. 
of proceeds generated by a self-liquidation of some of the companies in the SemCanada Group. Several unsecured creditors of the SemCanada Group objected to the proposed interim distribution. The matter thus came before Romaine J. of the Alberta Court of Queen's Bench for resolution in SemCanada.

The unsecured creditors objected to the interim distribution on several grounds, some of which were novel. They were summarized by Romaine J. as follows:

(a) the obligations of the SemCanada Group under the guarantee to the Lenders may be voidable as fraudulent preferences or fraudulent conveyances. The Court has insufficient evidence on that issue to grant the order sought, and the SemCanada Group should be compelled to provide further financial information and to answer specific questions on the issue during cross-examination on the affidavits;

(b) the amounts that the SemCanada Group are obligated to pay under the guarantee are expressly limited by the terms of the guarantee itself;

(c) the interim distribution may unfairly prejudice Canadian unsecured creditors and bestow an unwarranted benefit on unsecured creditors in the United States proceedings; and

(d) there is no urgency and a delay may provide more clarity with respect to the situation in the U.S. Chapter 11 proceedings. $^{9}$

\section{The Fraudulent Preference/Conveyance OBJection}

Justice Romaine first dealt with the objection that the obligations of the SemCanada Group could be voidable as a fraudulent preference or conveyance. She noted that "[i]t would not be normal practice in this kind of proceeding for the Monitor's counsel to address the possibility of fraudulent preference unless the Monitor is alerted to some evidence that this may be an issue," and that "in the normal course, it would be up to creditors, if they believe circumstances exist, to bring appropriate proceedings to attack the guarantee and Security Agreement." ${ }^{10}$ However, she went on to hold that, in these circumstances, it was not that simple.

The proposed order to allow the interim distribution contained an express declaration that the payment of such an interim distribution was not an unjust preference, fraudulent conveyance, or reviewable transaction. Justice Romaine pointed out that such declarations were common fare when seeking an interim distribution. ${ }^{11}$ The unsecured creditors seized on this language in the proposed order and used it to argue that this rendered the issue of whether there was a fraudulent preference or conveyance front-and-centre and that the matter should therefore be more heavily scrutinized. As part of that scrutiny, the unsecured creditors asked for an order that the SemCanada Group file more complete affidavits with financial statements and submit to cross-examinations on this issue. ${ }^{12}$ Justice Romaine refused this requested relief: 
It is not inappropriate for the applicants to ask for a declaration that the interim distribution is not a fraudulent preference or conveyance and such a declaration would arise from the Court's review of the relief sought as a part of CCAA process. Given the limited nature of what is being sought and the purpose of the proceedings, the creditors are not entitled to a full review of the possibility of historical fraudulent preferences or fulsome financial information from the CCAA debtors arising from this application standing alone. This does not preclude the unsecured creditors from applying to lift the stay to bring an independent action if they believe that it is justified by evidence. ${ }^{13}$

Although Romaine J. relied on no case law in making this decision, her reasoning is logical. Without any evidence before the Court that the security and guarantee granted by the three companies of the SemCanada Group were fraudulent, what the unsecured creditors were looking to do in this case was go on a "fishing expedition." 14 This would have all been done, as Romaine J. pointed out, without exposure on the part of the unsecured creditors to the potentially adverse costs consequences of a failed action to prove a fraudulent preference or conveyance. ${ }^{15}$

Indeed, Romaine J.'s reasoning aligns significantly with common law discovery principles, which also prohibit so-called "fishing expeditions." A plaintiff cannot ask for wide-ranging or unrestricted discovery on the grounds that he or she hopes what is found may allow the pleading of a cause of action. ${ }^{16}$ By the same token, a creditor cannot ask for further wide-ranging information and cross-examination from a debtor in the hopes that this will reveal a potential fraudulent preference, conveyance, or other reviewable transaction.

As Romaine J. stated, the situation would have been different if the monitor was alerted to a potential fraudulent preference or conveyance. In that situation, the monitor's duty would be to investigate the situation, which would likely preclude any interim distribution. Similarly, Romaine J. alluded to a situation where a creditor has evidence of a fraudulent preference or conveyance and brings an application to lift the stay for an independent action to prove the same. ${ }^{17}$

The situation might even have been different if the unsecured creditors had presented some evidence to demonstrate an arguable case of a fraudulent preference or conveyance in the circumstances. It is submitted by the authors that should a creditor oppose an application for interim distribution by presenting some evidence providing an arguable case that the underlying security, or perhaps the payment of the distribution itself, amounted to a reviewable transaction, the interim distribution application should, at the very least, be adjourned so that one, or possibly both, of the following may occur:

(1) The monitor, having been alerted to some evidence of a potential issue with the security, investigates the situation (or at least assesses whether it should investigate) and reports its findings to the court; and

Ibid.

Dow Chemical Co. v. Kayson Plastics \& Chemicals Ltd. (1966), [1967] 1 Ex. C.R. 71 at 75. See also Stone Sapphire Ltd. v. Transglobal Communications Group, 2007 ABQB 238, 416 A.R. 306 at paras. 71-72.

$17 \quad$ SemCanada, supra note 7 at paras. $12,15$. 
(2) The objecting creditor is given an opportunity to apply to lift the stay and advance an independent action to prove the reviewable transaction.

The chief difficulty with Romaine J.'s ruling is that it does not address a situation where a reviewable transaction is not discoverable (by the creditors or the monitor at least) until after the payment of an interim distribution. However, this is a risk in any interim distribution and the reason why courts in CCAA proceedings are reluctant to approve such distributions. The fact that the interim payments in SemCanada would have been payable to a syndicate of banks represented by the Bank of America reduced the risk of non-recovery should it subsequently turn out that monies had to be paid back.

\section{The Issue of Limiting ClaUses IN THE GUARANTEE}

Justice Romaine moved next to the second objection. To summarize, the unsecured creditors pointed to a limiting clause in the relevant guarantee, which they argued would limit the amounts guaranteed. That clause stated as follows:

The liability of each Guarantor hereunder shall be limited to the maximum amount of liability that can be incurred without rendering this Guaranty, as it relates to such Guarantor, voidable under applicable Law relating to fraudulent conveyance or fraudulent transfer, and not for any greater amount. ${ }^{18}$

Justice Romaine noted that this clause was designed to address an issue under U.S. corporate law, where there are restrictions on the ability of a corporation to provide a guarantee where doing so renders the guarantor insolvent. She went on to point out that, while similar restrictions might have existed for Canadian corporations in the past, such restrictions were no longer in force. Hence, this same issue does not arise under Canadian law. ${ }^{19}$

\section{Concluding on this point, she wrote that}

while this clause may have effect when construed under U.S. law to limit the guarantee to an amount that would not render the guarantors insolvent at relevant periods of time, there are no corresponding obligations under the laws of Alberta (the governing law of the guarantee) ... that would limit the amount of the guarantee arising from the potential of insolvency when the guarantee was granted, or to the asset value of the guarantor, net of unsecured indebtedness, as suggested by the unsecured creditors. ${ }^{20}$

Justice Romaine's reasoning is not open to question when the relevant guarantee is governed by Alberta law. However, this argument might be revisited where the law of the guarantee is not stated, or where the guarantee is governed by U.S. law.

Ibid. at para. 18.

Ibid. at para. 19.

Ibid. at para. 20. Several of the unsecured creditors sought leave to the Alberta Court of Appeal with respect to this aspect of Romaine J.'s judgment: ARC Resources Ltd. v. SemCanada Crude, 2009 ABCA 244, 457 A.R. 225. Justice Rowbotham denied leave, holding that " $\mathrm{t}]$ hese were issues of the interpretation of this guarantee and its related agreements. They are not of such significance to the insolvency practice so as to warrant leave to this court. They do not engage the interpretation of legislation” (at para. 10). 


\section{ThE UNFAIR PREJUdiCE ISSUE}

The third objection to the interim distribution was that such a distribution would unfairly prejudice the Canadian unsecured creditors and provide an unfair advantage to the U.S. unsecured creditors. In the U.S. Chapter 11 proceedings for SemGroup and its U.S. affiliates and subsidiaries, there were no plans to make a similar interim distribution. Since all of the SemGroup companies were liquidating to pay off what was essentially the same debt, the unsecured creditors argued that the interim distribution paid by the three SemCanada Group entities would create a situation "whereby the SemEnergy Group of debtor companies will have applied all of their assets to the secured debt, leaving their unsecured creditors without the possibility of recovery, while other debtor companies, including in the U.S. proceedings, will have their burdens reduced, making it possible that U.S. unsecured debtors will benefit disproportionally."21

This objection gave Romaine J. pause. She stated that

an application for an interim distribution to one creditor must be carefully scrutinized and found to be justifiable for good and sustainable reasons, recognizing that it may create a preference. The court is required to consider the advantages, disadvantages and potential prejudice of such an interim distribution to all the stakeholders of the debtor entity. ${ }^{22}$

The unsecured creditors' argument fit nicely within the above articulation of the considerations relevant to allowing or disallowing an interim distribution. Justice Romaine was "satisfied that an interim distribution to the [secured] Lenders gives rise to the possibility that unsecured creditors may be prejudiced and that such potential for prejudice outweighs the benefits of an early payment on the guarantee to the [secured] Lenders."23

The question arising out of this ruling is how to avoid a similar occurrence in a future cross-border insolvency.

Justice Romaine herself hinted in her decision that matters might have been different had the insolvency proceedings of SemGroup and the SemCanada Group been simple receiverships as opposed to U.S. Chapter 11 and concurrent CCAA proceedings. However, even if the SemCanada Group insolvency (and its U.S. SemGroup counterparts) had proceeded via receiverships as opposed to restructuring, it is not clear that the unsecured creditors could not have brought a successful objection to a similar interim distribution on

21 SemCanada, ibid. at para. 25. The alleged prejudice was similar in many respects to the oppression claimed by two sets of Ford Canada shareholders in Ford Motor Company of Canada v. Ontario Municipal Employees Retirement Board (2006), 79 O.R. (3d) 81 (C.A.). In that case, it was found by the Ontario Court of Appeal that Ford U.S. had oppressed the stakeholders of Ford Canada by maintaining a transfer pricing scheme to the detriment of Ford Canada, while Ford U.S. reaped some benefits of the same scheme. The similarity in reasoning between the oppression claimants and the arguments of unsecured creditors of the SemCanada Group are noticeable.

22 SemCanada, ibid. at para. 27. The secured lenders countered with several arguments, attempting to frame the CCAA proceedings as an "administrative convenience" more akin to a receivership and attempting to rely on subrogation rights in the guarantee (at para. 36). These were quickly rejected by Romaine J., who held that she could not ignore the fact that SemGroup and the SemCanada Group were, irrespective of the stated goal of liquidation, nonetheless in U.S. Chapter 11 and CCAA proceedings respectively and thus she could not ignore the goals of those statutes to maximize benefit for all creditors (at para. 29). She further held that the ability to subrogate was dubious (at para. 33). Ibid. at para. 36 . 
the same grounds. A court-appointed receiver has duties to all creditors and must also consider whether any type of distribution will unfairly prejudice a group of creditors. ${ }^{24}$ Consequently, the result may well have been the same even outside of the CCAA.

Summing up on this point, it may be that the only way for senior debt holders, debtors, and monitors to avoid the type of objection to an interim distribution successful in SemCanada is to ensure that such a one-sided interim distribution does not occur. The objection might have been rendered moot if SemGroup's U.S. affiliates and subsidiaries were simultaneously making a similar interim distribution. ${ }^{25}$

\section{THE LACK OF URGENCY ISSUE}

The final objection of the unsecured creditors was that there was no urgency for the interim distribution demonstrated and that even a short delay would allow time to gain insight into the SemGroup U.S. Chapter 11 proceedings. This ground of objection tied in with the third ground above. In this case there was no argument that an interim distribution was required for any reason other than the monitor stating that it was appropriate in the circumstances. Furthermore, as Romaine J. pointed out, the monitor had not addressed the potential prejudice to the unsecured creditors, which they had raised in their previous ground of objection. ${ }^{26}$

She went on to conclude as follows:

It is not necessarily the case that a distribution of funds from the Canadian estate must await the resolution of Chapter 11 proceedings in the United States. The Canadian CCAA proceedings may advance at a different pace if the Court is satisfied by evidence before it that it is appropriate to do so. In the case of this application, however, it is prudent to delay an interim distribution until there is sufficient information to better evaluate the potential of prejudice to Canadian creditors. ${ }^{27}$

The authors submit that if it is found that the potential prejudice to creditors outweighs the advantages of an interim distribution, no amount of urgency, whether it be demonstrated or not, will be sufficient to overcome the potential prejudice. Indeed, we would argue that urgency should be entirely subsumed into the advantage/disadvantage framework set out by Romaine J. when considering the third ground of objection, since making an interim distribution to address some emergent or urgent circumstance is undoubtedly an advantage to making a distribution.

In the result, Romaine J. adjourned the application for approval of the interim distribution sine die as premature, without prejudice to the secured lenders' ability to reapply "with more current information if it becomes apparent that the potential prejudice identified to the

Frank Bennett, Bennett on Receiverships, 2d ed. (Toronto: Carswell, 1999) at 450-52.

That being the case, steps would likely be required to ensure that any simultaneous interim distribution is near pro rata as between the U.S. and Canadian entities, otherwise the same objection could be raised in that one set of companies would be taking on the lion's share of liability, thereby reducing the potential liability of the other set of companies and possibly leaving more in the pool for the unsecured creditors of the latter.

SemCanada, supra note 7 at paras. 38-39.

Ibid. at para. 40 . 
unsecured creditors is unlikely to materialize, can be avoided by other measures or that the balance of prejudice and benefit has shifted.”28 No such an application was made.

\title{
B. CELTIC V. SEMCANADA
}

The SemCanada Group CCAA proceedings also saw an attempted priority claim made by creditors who would have otherwise been subordinated or unsecured. In one such attempt, two creditors, Auriga Energy Inc. (Auriga) and Celtic Exploration Ltd., who were producers of natural gas (the producers), applied to Romaine J. for a declaration that the proceeds of the sale of end products derived from the raw gas that the producers supplied to one company from the SemCanada Group were held in trust for the producers. ${ }^{29}$

SemCAMS ULC (SemCAMS) was an operator of four natural gas processing plants in Alberta. SemCAMS had entered into purchase and sale agreements with the producers for the purchase of raw natural gas. Under these contracts, the producers had the option of delivering the gas to SemCAMS plants for processing without an inlet sale, meaning that legally the producers would remain the owner of the gas through processing until a sale of the processed products was arranged. Alternatively, the producers could sell their gas to SemCAMS outright under the contracts, which gave the producers a better price point for their gas than the previous option. Justice Romaine found that the producers had elected the latter option in this case. ${ }^{30}$

The producers argued, nevertheless, that there was a trust relationship. Justice Romaine commented on the producers' trust arguments as follows:

\begin{abstract}
Both Producers submit that SemCAMS by its subsequent conduct and communications indicated that an agency relationship existed, giving rise to a trust relationship and fiduciary duties between them and SemCAMS. The Producers are sophisticated commercial parties who negotiated their contractual relationship with SemCAMS at arms-length. Courts are understandably slow to find a trust or to impose fiduciary obligations upon parties in such circumstances, without evidence of a clear intention to create such a trust: Hodgkinson v. Simms, [1994] 3 S.C.R. 377 (S.C.C.) at paras. 38-40; Lac Minerals Ltd. v. International Corona Resources Ltd., [1989] 2 S.C.R. 574 (S.C.C.) at paras. 27-29; Progas Ltd. v. AEC West Ltd. (2001), 295 A.R. 127, 106 A.C.W.S. (3d) 895 (Alta. Q.B.) at paras. 29-30. The Purchase Agreements do not contain any indication of an intention to create an agency agreement or a trust, and the evidence of conduct put forward by the Producers to show such an intention is weak, ambiguous and often denied or contradicted by SemCAMS. $^{31}$
\end{abstract}

As can be seen, the producers were attempting to escape the consequences of electing the second option under the plain terms of the purchase and sale agreements, which option backfired on the producers once SemCAMS became insolvent. Had they chosen to forego a better price for their gas and elected the first option under the purchase and sale agreements, they would have remained the owner of the gas and a trust or fiduciary

Ibid. at para. 41 .

Re SemCanada Crude, 2009 ABQB 398, 55 C.B.R. (5th) 284 [Celtic v. SemCanada].

Ibid. at paras. 3-4.

Ibid. at para. 7 . 
relationship based on agency might have arisen. ${ }^{32}$ Justice Romaine found that the producers were unable, on the facts, to prove a modification of the written terms of the contracts, or a termination thereof. Hence the producers' applications failed. ${ }^{33}$

Justice Romaine made a point of stating that there was conflicting affidavit evidence. The producers argued that the purchase and sale agreements had been modified by subsequent conduct. Auriga even submitted that one of the agreements had been effectively terminated. SemCAMS' evidence, not surprisingly, denied these facts and presented an entirely different story.

Justice Romaine pointed out the unsatisfactory nature of such conflicting evidence, stating that "[w]hile applications in CCAA proceedings often are heard on an urgent summary manner on the basis of affidavit evidence, I was unable to make findings of credibility on the basis of the evidence before me.”34 She went on to rule that "[t]he evidentiary burden was on Auriga to establish a termination [of the purchase and sale agreement], and it failed to do so."35

While the producers had little choice but to attempt to argue around the plain wording of the purchase and sale agreements, as the only other option was to be resigned to a loss of priority, there was likely not much hope of success on the producers' part. The unfortunate happenstance for the producers was that the particular purchase and sale agreements at issue in this decision contained an option that would have allowed the producers to maintain an ownership interest. Consequently, the tools were in place to protect against SemCAMS' insolvency, they just went unused.

This is not surprising given the state of the oil and gas market prior to the beginning of the latest recession. It is probably fair to speculate that the producers in this case were caught off guard by SemGroup's difficulties. As such, Celtic v. SemCanada best serves as an abject lesson of the consequences that might occur for a producer in the context of an unexpected insolvency.

\section{DifFICUlTIES IN ESTABLISHING SET-OFF IN THE SEMCANADA GROUP RESTRUCTURING}

While some producers involved in contracts with one or more of the SemCanada Group’s entities attempted to seek a priority ruling, others turned to the doctrine of set-off. Producers'

The producers would have, of course, had to engage in any end point sale negotiations along with SemCAMS, otherwise they risked not having the consignment purchase nature of their arrangement be known. This joint participation was comprehended in the purchase and sale agreements, as summarized above.

Celtic v. SemCanada, supra note 29 at para. 12

Ibid. Her views on this point are consistent with Lesalle Business Credit v. Genfast Manufacturing (2008), 45 C.B.R. (5th) 55 at paras. 14-15, 40 (Ont. Sup. Ct. J.). In that case, Campbell J. made similar comments regarding how a proposed creditor could not meet its burden and that making a decision on negligent misrepresentation based on affidavits and transcripts was not ideal. 
attempts to use set-off are not novel ${ }^{36}$ and, indeed, are expected in the context of an oil and gas company insolvency. There were no less than three reported decisions on the issue of setoff in the SemCanada Group restructuring.

\section{A. SEMCANADA V. NEXEN}

In the first of the three decisions, ${ }^{37}$ Nexen Marketing (Nexen) had attempted to set-off amounts owed to it under contracts with SemCanada Crude Company (SemCanada) and CEG Energy Options Inc. (CEG) against amounts owing by Nexen to SemCAMS. ${ }^{38}$ SemCAMS took issue with Nexen's ability to set-off and applied for an order that the amounts owed to it were due and payable and that Nexen had no entitlement to exercise setoff.

The contracts between SemCAMS and Nexen called for Nexen to purchase volumes of condensate from SemCAMS. The amount owing to SemCAMS at the time of the application was over $\$ 1.2$ million. ${ }^{39}$

During an overlapping period of time, Nexen and SemCanada were parties to month-tomonth oil purchase contracts where Nexen and SemCanada were both the purchasers and sellers of oil from one another. Similarly, during that same overlapping period, Nexen and CEG were parties to gas purchase contracts where Nexen and CEG were both the purchasers and sellers of gas from one another. For the period leading directly up to SemCanada Group's CCAA proceedings (namely June and July of 2008) it was SemCanada and CEG who owed funds to Nexen under these contracts. ${ }^{40}$ It was these amounts owing that Nexen attempted to set-off against the aforementioned \$1.2 million it owed to SemCAMS.

Justice Romaine summarized the principles to be applied to Nexen's set-off argument, which was based entirely on equitable set-off:

1. The party relying on a set off must show some equitable ground for being protected against his adversary's demands.

2. The equitable ground must go to the very root of the plaintiff's claim before a set off will be allowed.

3. A cross-claim must be so clearly connected with the demand of the plaintiff that it would be manifestly unjust to allow the plaintiff to enforce payment without taking into consideration the cross-claim.

See e.g. Re Blue Range Resource Corp., 1999 ABQB 1038, 245 A.R. 154, rev'd 2000 ABCA 200, 261 A.R. 162; NESI Energy Marketing Canada Ltd. (Trustee of) v. NGL Supply (Gas) Co. Ltd., 2001 ABCA 168, 281 A.R. 229. Trade creditors of insolvent oil and gas companies have also tried to employ set-off in Alberta in the context of the CCAA: see Montreal Trust Company of Canada Ltd. v. Smoky River Coal Ltd., 2001 ABQB 587, 292 A.R. 361.

37 SemCanada v. Nexen, supra note 6.

38 All three companies, SemCanada, CEG, and SemCAMS, were protected under the consolidated CCAA proceedings.

$39 \quad$ SemCanada v. Nexen, supra note 6 at para. 3.

$40 \quad$ Ibid. at para. 4. 
4. The plaintiff's claim and the cross-claim need not arise out of the same contract.

5. Unliquidated claims are on the same footing as liquidated claims. ${ }^{41}$

Nexen argued that the "clear connection" that entitled it to equitable set-off was established by the fact that the various SemGroup and SemCanada Group entities were all closely related; carrying on essentially the same business and marketing together as a group. At the same time, however, Nexen was clear that it was not seeking to lift the corporate veil, as that would be a grounds to claim for legal set-off. ${ }^{42}$

Justice Romaine rejected Nexen's argument of close connection. In applying the criteria set out by the Supreme Court in Telford, Romaine J. noted that the claims in this case did not arise out of the same contract. While she went on to say that this was not required, many of the cited cases for equitable set-off did contain claims arising from the same contract. She stated that what was required was that "the cross-claims sought to be set off by Nexen to be so clearly connected with the claim of SemCAMS [ULC] 'that it would be manifestly unjust to allow [SemCAMS] to enforce payment without taking into consideration the crossclaim. "'43 She further relied on a passage from Telford stating that only cross-claims that directly impeach the demands of the other party can be deducted. ${ }^{44}$

She went on to deny Nexen's attempted set-off, holding that it was the claims themselves that must be closely connected. The close connection of the corporations that were parties to the transactions was insufficient to establish this element of the test for equitable set-off. ${ }^{45}$

Nexen further argued that it was unfair that two members of the SemCanada Group were shielding themselves behind CCAA proceedings, while a third member could compel full payment. Justice Romaine was not persuaded. She held that this unfairness argument might have had some merit if made in conjunction with the other elements required to make out equitable set-off, but since those elements had not be established, this ground was insufficient on its own. ${ }^{46}$ She went on to conclude on this point that, "[a]s pointed out by the Court of Appeal in Nesi Energy Marketing Canada Ltd. (Trustee of) v. NGL Supply (Gas) Co. ... the 'requirements for set-off are not relaxed because of the insolvency context."'47

The authors support this reasoning. Indeed, if CEG, SemCanada, and SemCAMS were all subject to separate CCAA or insolvency proceedings, the result would be undeniable. As a matter of law, it should not change simply because the proceedings were consolidated in this case.

However, Nexen's argument did stem from a practical concern. In a different (but similar) fact situation, one could see how a decision such as that in SemCanada v. Nexen could be used to force a creditor to fund its own compromise under a plan. For example, take the

Holt v. Telford, [1987] 2 S.C.R. 193 at para. 34 [Telford], cited in ibid. at para. 6 [citations omitted]. SemCanada v. Nexen, ibid. at para. 11.

Ibid. at para. 7, citing Telford, supra note 41 at para. 37.

SemCanada $v$. Nexen, ibid. at para. 8, citing Telford, ibid.

SemCanada v. Nexen, ibid. at para. 9.

Ibid. at para. 19.

Ibid. at para. 20 [citation omitted]. 
hypothetical situation where a creditor owes a substantial sum to A, who is under common $C C A A$ protection with its affiliate $\mathrm{B}$, and where $\mathrm{B}$ owes an even more substantial sum to the creditor. In such a case, the payment to A by the creditor, which under the reasoning in this case is unlikely to be avoided, might well be turned around into an offer of compromise, for cents on the dollar, regarding the creditor's claim against B.

While that may not be a preferable effect of a joint CCAA proceeding, the alternative of requiring separate $C C A A$ proceedings for affiliated companies is even less practical. There are obvious advantages to allowing subsidiaries and affiliates to participate in joint plans of arrangement under the CCAA. Requiring separate proceedings for each affiliate or subsidiary not only creates an undue multiplicity of proceedings, but negates these advantages. Additionally, the practical reality is that complex restructurings would not be feasible without the joint participation and the pooling of resources from parents, subsidiaries, and affiliates. Consequently, requiring separate proceedings for the sole reason of avoiding a result similar to this case is not a supportable solution.

The situation might have been different if SemCanada Group was engaged in a more vertically integrated business. The situation in this case arose out of the horizontal integration of the SemCanada Group. SemCAMS was buying and selling condensate, SemCanada oil, and CEG gas. Each of the SemCanada Group companies was producing or buying a different product (thus requiring a separate contract with each). In a situation where there is one contract to purchase an end product with one company, and its affiliates and subsidiaries work together with the company to produce and deliver it, there could well be a claim for equitable or legal set-off pursuant to the "group enterprise" theory of liability. ${ }^{48}$ That was not the situation in this case, however. ${ }^{49}$

Additionally, Nexen (and indeed any seller of oil and gas) likely had the option to better protect itself through contract. Set-off provisions in the relevant purchase and sale contracts with the SemCanada Group entities that extended to related corporations might well be an option when contracting with entities that market or essentially function as a group. Such contractual provisions make it possible to claim contractual set-off against affiliates and subsidiaries. However, these contracts must be entered into properly, as our discussion below will illustrate.

See Plas-Tex Canada Ltd. v. Dow Chemical of Canada Ltd., 2004 ABCA 309, 357 A.R. 139. In that case, it was found that Dow Chemical, in fulfilling its contract with the plaintiff, had made use of several of its subsidiaries and affiliates in manufacturing the end product. This was sufficient to the Court of Appeal to ground liability in each separate legal entity based on the group enterprise theory of liability as a unit. This would likely be applicable in an insolvency situation to support equitable or legal set-off against common CCAA applicants where such applicants have worked together in a vertically integrated manner.

49 Nexen sought leave to appeal the judgment of Romaine J. to the Alberta Court of Appeal. Justice McFadyen denied this request for leave: Nexen Marketing v. SemCAMS ULC, 2009 ABCA 237, 457 A.R. 336. She held that Romaine J. made no error in stating the test for equitable set-off and essentially made a finding of fact with respect to a lack of connection between the contracts or transactions (at paras. 17-18). 


\section{B. TRILOGY V. SEMCANADA}

The next set-off decision within the SemCanada Group CCAA proceedings was a contest between Trilogy Energy LP (Trilogy) and SemCAMS. ${ }^{50}$ In this dispute, Trilogy claimed equitable, contractual, and legal set-off for amounts owing from SemCAMS for the latter's purchase of natural gas from the former.

SemCAMS was the co-owner and operator of 17 natural gas processing facilities in Alberta. As is common in the industry, SemCAMS operated these facilities pursuant to coownership and operating agreements between all the other co-owners. Trilogy itself was a co-owner in three of the aforementioned 17 facilities. SemCAMS's duties were to maintain all of these facilities and gather and process the natural gas. Pursuant to the operation agreements, each of the co-owners was entitled to use of a share of the throughput capacity of the respective facilities, with such share allocated in proportion to the respective coowner's ownership interest. Each of the 17 facilities had a separate joint account that SemCAMS, as the operator, administered.

SemCAMS, as an operator of these 17 facilities, gathered and processed raw natural gas for Trilogy pursuant to various processing agreements. Trilogy owed around \$5.3 million (plus interest) to SemCAMS as operator for services provided under these processing agreements. $^{51}$

In April of 2008, Trilogy had sold raw natural gas to SemCAMS pursuant to an Inlet Purchase Agreement (IPA). Under that agreement, ownership in the gas passed specifically to SemCAMS. As at the date of the CCAA filing, about \$4.1 million was owed from SemCAMS to Trilogy under the agreement. This is the amount that Trilogy sought to set-off against the aforementioned \$5.3 million that it owed under the processing agreements.

\section{THE TRUST IsSUE}

Trilogy also sought to set-off amounts owing to SemCAMS under the co-ownership and operating agreements. These amounts related to Trilogy's proportionate share of operating expenses and capital expenditures for the three facilities in which Trilogy was a co-owner. Justice Romaine dealt with that argument rather swiftly by referring to the Alberta Court of Appeal's decisions in Bank of Nova Scotia v. Société Générale (Canada) ${ }^{52}$ and Brookfield. ${ }^{53}$ She held that the monies intended for the joint accounts of each facility in which Trilogy was a co-owner were held expressly in trust on behalf of all co-owners. Accordingly, there could be no set-off of those trust funds owed to SemCAMS qua operator against funds owed by SemCAMS in its individual corporate capacity. ${ }^{54}$

Re SemCanada Crude, 2009 ABQB 397, [2009] A.J. No. 895 (QL) [Trilogy v. SemCanada]. SemCAMS was the sole owner (or lessee) and operator of four other natural gas processing facilities, for which there were consequently no co-ownership and operating agreements. Trilogy owed around $\$ 68,000$ with respect to similar gas processing agreements done at these facilities. Because there was no co-ownership agreement or other interest participation matters, it was conceded that Trilogy was entitled to set-off for the full \$68,000 regarding the SemCAMS 100 percent owned facilities: ibid. at para. 6.

(1988), 87 A.R. 133 (C.A.).

Supra note 2.

Trilogy v. SemCanada, supra note 50 at paras. 21, 32. 


\section{The CONTRACtuAl SET-OFF IsSUE}

Justice Romaine also rejected Trilogy's arguments of contractual set-off, finding no provisions in any of the relevant agreements that specifically entitled Trilogy to set-off. There were non-reciprocal clauses in some of the co-ownership and operating agreements giving the operator a right of set-off. However, a specific right of contractual set-off to the operator was held not to create an implied and unstated right of set-off to a co-owner. ${ }^{55}$

\section{ThE LEGAL SET-OFF IsSUE}

In dealing with Trilogy's legal set-off argument, Romaine J. cited the well-known test from Telford. Legal set-off requires the debts to be both liquidated and mutual crossobligations. Further, citing Citibank Canada v. Confederation Life Insurance, ${ }^{56}$ "[m]utual cross-obligations are cross-claims between the same parties and in the same right."

There was no issue that the debts were liquidated. The objection on SemCAMS' part was that they were not cross-claims between the same party and in the same right. Justice Romaine agreed that they were not. She held that, "[w]hether debts are in the same right depends upon whether the debtor and creditor are liable solely to each other or to each other jointly with third parties." 58 She went on to hold that even if SemCAMS was not acting as a trustee for the joint owners under the co-ownership and operating agreements, it was at least acting as an administrator of a special purpose account. As such, it would be misappropriation of the joint owner's share of that account if it were used to set-off SemCAMS' debt in an individual capacity. ${ }^{59}$ Consequently, it made no difference to Romaine J. whether SemCAMS was acting as a trustee or an administrator of a special purpose account. The significant fact was that it was contracting as the operator of the facilities. Therefore, the debt owed by SemCAMS in its individual capacity could not be setoff against the monies owed by Trilogy to the operator. ${ }^{60}$

Trilogy countered the foregoing by arguing that, at the very least, its debt should be set-off in an amount equal to SemCAMS' share of revenues in the joint accounts. ${ }^{61}$ However, it was pointed out that determining the share of SemCAMS under the joint accounts was subject to complex accounting and year-end adjustments and thus was not a candidate for legal setoff. $^{62}$

The authors believe that the basis of this rejection could only have been that SemCAMS' share of the joint account could not be considered liquidated, owing to the fact that it could only be ascertained through complex accounting and adjustments. Thus it was not ascertainable at the time of the application, which is a required aspect of a liquidated cross-

Ibid. at paras. 22-25.

(1996), 42 C.B.R. (3d) 288 (Ont. Ct. J. (Gen. Div.)), aff'd (1998), 37 O.R. (3d) 226 (C.A.).

Trilogy v. SemCanada, supra note 50 at para. 29, citing ibid. at para. 37.

Trilogy v. SemCanada, ibid. at para. 30.

Ibid. at para. 31.

Ibid. at paras. 31-32.

Ibid. at para. 33.

Ibid. at para. 35 . 
claim for legal set-off. ${ }^{63}$ That being the case, we agree with Romaine J.'s reasoning with respect to legal set-off. However, we believe this same reasoning creates a potential future issue in regards to equitable set-off if the amounts sought to be set-off arose as between the co-ownership and operating agreements, and the gas processing agreements.

\section{THE EQUITABLE SET-OFF ISSUE}

Trilogy also argued equitable set-off. Justice Romaine set out the same authorities for equitable set-off as she did previously in SemCanada $v$. Nexen, noting that it is very important that the transactions be closely connected to invoke equitable set-off. Justice Romaine cited this as her prime consideration on the facts of this case. ${ }^{64}$

Although the amounts Trilogy sought to set-off did not arise out of the same contract, Trilogy argued that they were nevertheless sufficiently close in connection to permit equitable set-off.

Trilogy's first submission on this point was that since SemCAMS and Trilogy were parties to multiple, complex agreements respecting the processing of gas, all of the debts arising under the various agreements were therefore related. ${ }^{65}$ Justice Romaine rejected this submission. She pointed out that there was no cross-accounting as between the various facilities operated by SemCAMS and that the only relationship between the co-ownership and operating agreements, and the gas processing agreements was that they all related to the gathering and processing of Trilogy's natural gas, through various facilities operated by SemCAMS, but all subject to various co-ownerships. The IPA was viewed by Romaine J. as the only agreement of its kind because SemCAMS had contracted in its own right (and not as operator). ${ }^{66}$

Justice Romaine went on to hold that this lack of mutuality, although not required for equitable set-off, sufficiently distinguished the IPA amounts from amounts owing under the co-ownership and operating agreements, and the gas processing agreements. This lack of connection and mutuality was sufficient for Romaine J. to deny equitable set-off on Trilogy's first ground. ${ }^{67}$

While the authors agree with the reasoning of Romaine J. insofar as the amounts sought to be set-off with respect to the IPA, we believe that an open issue may remain. While the IPA was properly held to be far removed from any connection with the other agreements related to the facilities, a different circumstance would have arisen if Trilogy was seeking to set-off amounts as between the co-ownership and operating agreements, and the gas processing agreements. 
For example, if a hypothetical producer is also a co-owner of a facility and employs the facility to process its gas, a situation may exist where the producer owes the operator of the facility pursuant to an agreement akin to the gas processing agreements in this case, while at the same time the producer may be owed a share of revenue pursuant to an agreement akin to the co-ownership and operating agreements in this case. Although, as discussed above, pursuant to the legal set-off analysis, precisely what the producer is owed is unliquidated (and likely cannot be calculated absent complex accounting proceedings and adjustments), while the amount owed under the processing agreement would be liquidated. However, this is no bar to equitable set-off. ${ }^{68}$ Moreover, there is likely a sufficient connection between the transactions given that the amounts owed to the producer would arise in whole or in part out of the revenue generated by the processing of the producer's gas at the facility. The producer (who is also a co-owner) would thus be entitled to its share of revenue minus operating and capital expenditures. The operator is under a fiduciary duty to account to all owners including, in this hypothetical, the producer. The authors submit that such a situation gives rise to a much stronger argument of equitable set-off between a producer who is also a coowner of a facility and the operator of the facility. ${ }^{69}$

Significantly, however, the above hypothetical is removed from Trilogy's argument in this case since Trilogy owed amounts to SemCAMS as operator under the co-ownership and operating agreements, and the gas processing agreements and was seeking set-off against the separate IPA. Accordingly, any analysis of the foregoing hypothetical must await a case more factually on point.

Returning to the case, Trilogy's second argument regarding equitable set-off was that the gas processing agreements were not distinct contractual obligations after all, owing to the fact that the IPA incorporated and built on previously existing provisions in the gas processing agreements. The provision of the IPA most heavily relied on by Trilogy in support of this argument stated that the processing fees were to be charged on the same basis as the capital fees set out in the gas processing agreements between SemCAMS and Trilogy. ${ }^{70}$

Justice Romaine rejected this argument as well. She ruled that when she read the incorporated provision in the context of the IPA as a whole, the provision in question merely referenced how the final price for natural gas would be calculated. While capital fee components in the price were "benchmarked" to four of the previously executed gas processing agreements, there were no other references to those agreements within the IPA. Therefore, Romaine J. held that there was

certainly nothing to suggest that any of them are incorporated into the Inlet Purchase Agreement. The Inlet Purchase Agreement is not a continuation of the Gas Processing Agreements. It is not contingent on them, and there are no cross-termination provisions. ${ }^{71}$ not invariably be so in an insolvency situation involving an operator.

Trilogy v. SemCanada, supra note 50 at para. 47.

Ibid. 
Trilogy may have successfully negotiated the IPA to be more incorporative of the gas processing agreements. However, the authors are dubious that this would have made any difference to the result. Since SemCAMS collected revenue under the gas processing agreements on behalf of all owners of the facilities it becomes increasingly improbable that the IPA could establish a sufficiently close connection with the gas processing agreements, unless it too was undertaken by SemCAMS on behalf of all co-owners of the facilities.

For the same reason, a set-off clause could not be added to the IPA allowing set-off against the co-ownership and operating or gas processing agreements. As the operator, SemCAMS could not unilaterally agree to add this type of clause absent the authorization of all the co-owners of the facilities, as to do so without authorization would be a flouting of its responsibilities as operator. Moreover, the co-owners of the other facility have no incentive to allow for such a clause since the IPA was solely for the benefit of SemCAMS and the other agreements were for the benefit of all co-owners of the facilities. There is no persuasive reason why, in the ordinary course, the other co-owners would allow a producer to set-off amounts owed to their benefit against amounts SemCAMS owed in its individual capacity.

Concluding on all the arguments regarding close connection, Romaine J. held that she was not satisfied that Trilogy had demonstrated sufficiently close connections among the debts it sought to set-off. ${ }^{72}$ She further held that, even if she had found such a close connection, she would not have found it manifestly unjust to allow SemCAMS to enforce payment against Trilogy. As she wrote, “[g]iven the differences in the contracts, both in purpose and in the contracting parties, it cannot be said that it would be manifestly unjust to Trilogy to enforce its indebtedness under the IPA. The IPA was a special-purpose contract, out of the pattern of previous contracts."73

While Romaine J. continued on to discuss manifest unfairness, the nail had already been placed in the coffin of Trilogy's equitable set-off arguments. ${ }^{74}$

Owing to the result in this case, it is likely that where a party seeks to set-off amounts owed by an operator in its personal capacity against amounts owed to the operator in its capacity as operator, such an attempt may be doomed at the outset. Any set-off against amounts owed by an operator in its capacity as operator must be against amounts owed by the operator in that same capacity. Otherwise there will not be a sufficiently close connection.

\section{HUSKY V. SEMCANADA}

The final decision in relation to set-off in the context of the SemCanada Group CCAA proceedings was a dispute between Husky Energy Marketing Inc. (Husky) and SemCanada. ${ }^{75}$

Ibid. at para. 56 .

Ibid. at para. 57.

Trilogy sought leave to appeal Romaine J.'s judgment to the Alberta Court of Appeal: Trilogy Energy LP v. SemCAMS ULC, 2009 ABCA 275, 460 A.R. 269. Justice Paperny denied leave, stating that many of Romaine J.'s findings were factual and thus entitled to deference. She had made no prima facie error in her applications of the legal tests for set-off and an appeal would unduly delay and hinder the rest of the SemCanada Group CCAA proceedings (at paras. 25-30).

75 Re SemCanada Crude, 2009 ABQB 715, 61 C.B.R. (5th) 242 [Husky v. SemCanada]. 
Husky argued that it was entitled to contractual set-off of monies it owed to SemCanada against monies owed to Husky by SemCanada’s U.S. affiliate, SemCrude.

The contracts between SemCanada and Husky entailed five separate agreements for the purchase and sale of oil. All five contracts had appended terms and conditions authored by Husky. No other principle of set-off was argued other than contractual. Accordingly, Romaine J. held that "[i]t is common ground that the right to contractual set-off, if it exists in these circumstances, must be found in sections 14 and 18 of the [terms and conditions]."

Section 18 of the terms and conditions allowed Husky to take certain actions in the event that SemCanada filed a proceeding for protection from its creditors (something that SemCanada admitted to doing in this case). One of the actions Husky could take was to "setoff amounts and/or deliveries as provided for in Section 14 herein."77

Section 14 stated that should the buyer or the seller fail to pay for or deliver the oil, as the case may be, the party not in default of its obligation would be entitled to set-off any or all of the amounts or deliveries owed against any other deliveries or payments that the nondefaulting party owed the defaulting party. Moreover, s. 14 stated that a party would include an affiliate of each party. ${ }^{78}$

Accordingly, this case turned on contractual interpretation. After citing well-known Alberta case law regarding contractual interpretation, Romaine J. summarized the arguments of both SemCanada and Husky.

SemCanada argued that, while there might well have been a triggering event under ss. 14 and 18 of the terms and conditions, it had to be interpreted such that for a set-off to arise there had to be a buyer who failed to make timely payment of amounts due for crude oil under a contract governed by the terms and conditions or, alternatively, a seller who failed to make timely delivery of crude oil. SemCanada further argued that the only default of a contract governed by the terms and conditions in this case was that Husky, in these circumstances a buyer, had failed to make payments for delivery of crude oil. Accordingly, in SemCanada's submission, the non-defaulting party was SemCanada and, therefore, only SemCanada had the right to set-off. ${ }^{79}$

Husky countered that SemCanada's interpretation of the contract had to be erroneous because it would have the effect of "limiting ... the use of options available to a Performing Party [the party not in default] under section 18, depending on the circumstances” that led to a default. ${ }^{80}$ 
In rejecting Husky’s argument, Romaine J. held as follows:

While [the effect of SemCanada's interpretation might limit the use of options, as argued by Husky], that does not make section 18 commercially unreasonable or ineffective. Section 18 provides for a list of options, "any or all" of which may be available to a Performing Party if section 18 is triggered by one or more of the listed breaches. A plain reading of section 18 indicates that the parties did not intend all of these options to be free-standing, as, for example, both subsections (b) and (c) refer to other provisions of the [terms and conditions] for their implementation. While one of the options may not be available given the circumstances in effect at the time of the triggering event, this does not mean section 18 (c) is unnecessary in any scenario. As submitted by SemCanada Crude, section 18 provides an additional trigger to invoke a right to set-off that would not otherwise be available to a party if the right was only exercisable in the circumstances that arise under section $14 .^{81}$

Justice Romaine concluded on this point by stating that, "[t]o interpret section 14 in the manner suggested by [Husky] would be to give a party that is a Performing Party under section 18 the right to set-off even if it is not in default under section $14 .{ }^{\prime \prime 2}$ She held that this simply could not have been the intent of the parties to the terms and conditions as was evident from the clear reference to s. 14 in s. 18.

In other words, Romaine J. held that the terms and conditions only comprehended that a party in default under s. 14 would be the party that filed a proceeding for protection from creditors (thereby triggering s. 18). What the contract did not provide for, or apparently even comprehend, was a situation where the party not in default under s. 14 was the party filing for protection from its creditors.

As should be obvious, the way around this ruling is to draft the contract such that any party clearly has the right to set-off. For example, nothing would have prevented Husky and SemCanada from agreeing to language in the terms and conditions such that the filing or protection from creditors was a default in and of itself, automatically giving the non-filing party the right to contractual set-off in the ensuing insolvency. Indeed, this particular ruling seems confined to the facts of this case as it is common in many contracts to have proper contingencies in place for an act of insolvency.

The other issue faced by Husky was that, even if its interpretation was correct, they were purporting to bind SemCrude with the terms and conditions in the absence of privity, a common practice for many contracts in the Alberta oil and gas industry. Justice Romaine held that such an arrangement is indeed possible and that contractual set-off could be agreed to amongst affiliates. However, she qualified that it would only be effective with the consent (and presumably the signature of a party to be charged) of those affiliates. ${ }^{83}$

This raises another practice point. While there is nothing preventing the inclusion of a right of set-off between affiliates, to ensure that the right is effective there should be privity of contract. This may be logistically and practically difficult in many circumstances as 
contracts such as those at issue in this case are entered into frequently in the oil and gas industry. However, it is at least theoretically possible. ${ }^{84}$

Moreover, where it is a parent entering into a contract on behalf of a subsidiary that it directly controls, or perhaps purports to bind its subsidiary, it may not be as simple to then say that there is an outright requirement that the subsidiary also execute the contract. ${ }^{85}$ In the result, this case may not stand for the proposition that every contract entered into in the oil and gas industry that purports to bind affiliates that are not signatories is vulnerable to a lack of privity argument.

As argued above, it is conceivable that a properly drafted contract providing set-off rights against affiliates and signed by the same affiliates would have engendered a different result in SemCanada v. Nexen. In that case, Nexen would likely have had a contractual right of setoff. Accordingly, there may well be utility in setting up such a scheme, albeit that it must be done in such a manner as to address the fatal flaws in Husky v. SemCanada.

\section{THE USE OF A RECEIVER IN THE CANADIAN SUPERIOR ENERGY INC. RESTRUCTURING}

CSEI, a publicly traded Alberta oil and gas company with assets primarily in Western Canada and Trinidad and Tobago, acquired rights to explore and produce hydrocarbons in the Intrepid Block, an 80,000 acre area offshore of Trinidad and Tobago (Intrepid Block). CSEI acquired such rights pursuant to a production sharing contract (PSC) for Block 5(c), dated 20 July 2005, entered into between CSEI and the Trinidad and Tobago Ministry of Energy and Energy Industries (the Minister).

CEC was a publicly traded Canadian corporation related to CSEI. CEC and CSEI were parties to an amended and restated participation agreement dated 30 December 2005. Pursuant to the participation agreement, CEC had a contingent right to earn a 25 percent interest in the PSC.

On 11 August 2007, CSEI and the global energy giant BG International Limited (BG) entered into a farm-in agreement pursuant to which BG farmed into Block 5(c) in exchange for a commitment to take part in a three-well exploration program. BG was obliged to pay 40 percent of the Phase I exploration costs to earn a 30 percent share in Block 5(c). The three wells were drilled and natural gas was discovered in all three locations. the University of Alberta, suggested that all entities that were intended to be bound execute consent pages as schedules to any such agreement and that all such consents would be supported by consideration. The authors agree that this is one of many potential solutions. able to covenant that such subsidiaries will abide by or enter into the agreement. Of course, this analysis becomes complicated when the subsidiary has an independent board of directors or other aspects of a separate corporate personality. It is further complicated by the wording of any covenant. Additionally, separate corporate personality and the autonomy of corporations to control themselves are appealing counter-arguments, as was fairly pointed out to the authors by some of the attendees at the 2010 Canadian Energy Law Foundation Conference. 
Also, on 11 August 2007, BG, CSEI, and CEC entered into a JOA in relation to the joint exploration, approval, development, production, and disposition of hydrocarbons from Block 5(c). CSEI was the operator under the JOA. CSEI held a 70 percent participating interest under the JOA, with BG in control of the remaining 30 percent (CEC had not yet earned an interest in the PSC when the events described below occurred, although CEC did not concede this). The parties utilized the common form of international JOA approved by the Association of International Petroleum Negotiators.

On 6 February 2009, BG issued a Notice of Default under art. 8 of the JOA to CSEI and also issued a Notice of Removal as Operator under art. 4.10 thereof.

On 9 February 2009, BG commenced arbitration proceedings against CSEI in the London Court of International Arbitration, alleging that CSEI had breached, and was in default of, a number of its obligations under the JOA, inter alia, by not paying its share of the joint account expenses payable under the JOA when due, and alleging commingling and misappropriation of joint account funds by CSEI. BG sought orders, inter alia, declaring that CSEI had breached the JOA and a full accounting of the joint account.

CSEI denied that it had misappropriated any funds and responded that any monetary default under the JOA was that of CEC, and that BG had acknowledged CEC's participation in the exploration program, although CEC had not yet earned its interest pursuant to the participation agreement. CSEI also counterclaimed, alleging that BG itself was in breach of its obligations triggered by the Notice of Default given by BG under the JOA.

Contemporaneous with the commencement of the arbitration, and prior to an arbitral tribunal being constituted, BG also commenced emergent proceedings in the Alberta Court of Queen's Bench for the appointment of an interim receiver of CSEI's participating interest under the JOA, its rights as operator for the joint account, and for the receiver to have exclusive charge and conduct of all joint operations. ${ }^{86}$ Twenty-four hours' notice of the application (to be heard on 11 February 2009) was given to CSEI. BG alleged that the matter was urgent because of the risk that an unpaid drilling contractor might terminate its contract with CSEI and leave the drilling wellsite. ${ }^{87} \mathrm{BG}$ indicated that it was "unwilling to advance funds to CSEI as Operator without ensuring the funds [were] adequately protected and handled by a [receiver] performing the functions of Operator." ${ }^{88}$ BG stated that it believed that the remedies under the JOA were insufficient to protect BG.

Despite CSEI's opposition to BG's application for appointment of the receiver and CSEI's request to be allowed time to cross-examine and file affidavits, an order was granted on 11 February 2009 by the Court of Queen's Bench appointing Deloitte \& Touche Inc. as receiver. ${ }^{89}$ The effect of the receivership order was to place the receiver in control of CSEI's participating interest in Block 5(c) and to substitute the receiver for CSEI as the operator. 
The receivership order contained some unusual provisions. The receiver was placed in exclusive charge and conduct of all joint operations. It was authorized to "retain BG to assist it in carrying out its duties," and to create a new receiver's joint account, which would function and operate as a separate joint account. ${ }^{90}$ The receiver was absolved from environmental liabilities (despite the fact that the Block 5(c) wells were situated in the territorial waters of Trinidad and Tobago and that the PSC was governed by the laws of that country). A receiver's charge was created against both BG and CSEI's participating interests in priority to all existing security interests in order to secure the costs of the receiver and its counsel. It was directed that the receiver's expenses shall be for the joint account. A receiver's borrowing charge against the whole of CSEI's participating interest was created to a maximum of US\$47 million as security for the payment of monies by the receiver, subordinate in priority only to the receiver's charge and a charge created by the receivership order in favour of Canadian Western Bank (CWB) in respect of a \$14 million debt. ${ }^{91}$ The receiver was authorized to issue receiver's certificates for any amount borrowed by it. Leave was given to the receiver to apply to the Court to "sell, assign or convey CSEI's Participating Interest or any part thereof in order to collect upon or realize any amount borrowed under any Receiver's Certificates."92

Pursuant to the powers granted to it by the receivership order, the receiver took charge of the Block 5(c) operations. The receiver sought legal advice in Trinidad and Tobago about an application to have the receiver recognized in the courts of that country. Such an application was not immediately made because applications of that nature were apparently novel in Trinidad and Tobago and it was uncertain whether the courts of Trinidad and Tobago would recognize the appointment of the receiver.

After the receivership order was granted, CSEI applied to the Alberta Court of Appeal to stay the receivership order pending the hearing of an appeal against the receivership order. One of CSEI's arguments was that it was improper for the Court of Queen's Bench to appoint a receiver where the JOA exhaustively governed the relationship between the parties. CSEI argued that the JOA governed the parties' rights in event of default, that the JOA provided adequate remedies, that BG's real goal was to better its contractual position, and that the removal of CSEI as operator violated the JOA. ${ }^{93}$

The Court of Appeal heard the application for an order staying the receivership order over a number of days during the last week of February 2009. By that point, CSEI was feeling the impact of the receivership order. Word had gotten out to its creditors, and the perception was that CSEI itself was in receivership. The Court remarked that a conservation order rather than a receivership order would not have attracted the same attention and caused the same damage. ${ }^{94}$ Despite finding that there was a serious arguable issue about whether the receivership order should have been issued when other remedies may have sufficed, the Court refused to stay the receivership order. The Court was concerned that such a stay would cause further instability and endanger the Block 5(c) project because, by then, the receiver

Ibid., Sch. A at 3, 5 .

Ibid., Sch. A at 6.

Ibid., Sch. A at 7.

BG International Limited v. Canadian Superior Energy, 2009 ABCA 73, 448 A.R. 24 at paras. 8-9. Ibid. at para. 16. 
had assumed operatorship. ${ }^{95}$ Accordingly, the Court ruled that the balance of convenience was in favour of not staying the receivership order.

While the hearing of the appeal (scheduled for 10 March 2009) was still pending, CSEI filed for protection under the CCAA on 4 March $2009 .{ }^{96}$ By that time, CEC had obtained CCAA protection (on 27 February 2009), which precluded CSEI from proceeding with the recovery of an amount of approximately $\$ 40$ million owed by CEC to CSEI. CSEI was also under considerable pressure from its own creditors because of the receivership order. The primary purpose of the CCAA proceedings commenced by CSEI was to protect its interest in Block 5(c), in which it had by then invested more than US\$70 million. Article 8(4)(d) of the JOA purported to give a non-defaulting party such as BG certain rights of forfeiture, and CSEI required those rights to be stayed.

On 5 March 2009, the Court of Queen's Bench granted an initial order extending protection to CSEI under the CCAA. The initial order expressly carved out the receiver from that order. The order further provided that in the event that the receivership order was upheld by the Court of Appeal, the monitor appointed by the initial order would keep the receiver informed of all marketing plans involving Block 5(c). The initial order directed CSEI, in the event that the receivership order was upheld by the Court of Appeal, to co-operate with the receiver for the purposes of having the receiver's appointment recognized by the courts in Trinidad and Tobago. ${ }^{97}$ This direction resulted in the High Court of Justice of the Republic of Trinidad and Tobago granting an order on 29 April 2009, recognizing the receivership order, and authorizing the receiver to exercise its powers under the receivership order in Trinidad and Tobago. The order was granted pursuant to a joint application by the receiver and CSEI and therefore by consent. Whether notice of the application was given to the Minister is not known.

The stay period imposed by the initial order was expressly qualified not to "operate, stop or delay any time which may be running under the JOA in connection with the Default Notices."98 The arbitration was also excluded from the prohibition against the continuation or commencement of proceedings. ${ }^{99}$ The effect of such exclusions on BG's alleged right of forfeiture was not clear and subsequently became the subject of further dispute in the CCAA proceedings. ${ }^{100}$ However, it became unnecessary for such issue to be decided by the Court of Queen's Bench, or in the arbitration, because eventually the Court approved a plan of arrangement in respect of CSEI, the effect of which was to also resolve this issue. ${ }^{101}$

Ibid. at paras. 21, 23-24.

Re Canadian Superior Energy (5 March 2009), Calgary 0901-02873 (Alta. Q.B.). The initial order can be found online: Hardie \& Kelly <http://www.relieffromdebt.ca/documents/cse/Initial\%20Order.pdf>. Borden Ladner Gervais, LLP was retained as counsel for CSEI later in 2009 after the Court of Appeal had given its judgment, and part way into the CCAA proceedings.

Ibid. at 7-8.

Ibid. at 10 .

Ibid.

Ibid.

Re Plan of Compromise or Arrangement of Canadian Superior Energy (14 August 2009), Calgary 090102873 (Alta. Q.B.). The plan can be found online: Hardie \& Kelly <http://www.relieffromdebt.ca/ documents/cse/Plan\%20of\%20Arrangement.pdf>. 
On 7 April 2009, the Alberta Court of Appeal dismissed CSEI's appeal against the granting of the receivership order. ${ }^{102}$ The Court did not agree with CSEI's argument that BG was not entitled to bypass the remedies in the JOA and use the receivership process to gain remedies to which it may not have been entitled under the JOA and the arbitration. The Court held that art. 18 of the JOA expressly provides that the remedies under the JOA are in addition to any other rights and remedies that may be available to a non-defaulting party whether at law, in equity, or otherwise. ${ }^{103}$ The Court proceeded to find that the enhanced security collaterally obtained by BG through the use of receiver's certificates had not been shown to create any serious prejudice to CSEI. It held that BG "had a reasonable concern about the protection of future advances" under the JOA because of the commingling of funds by CSEI. ${ }^{104}$ The effective displacement of CSEI as operator was seen by the Court of Appeal as an acceptable acceleration of the same right under the JOA. ${ }^{105}$ The Court concluded that "[t]he chambers judge had to make a difficult decision in a very short period of time," and had exercised her discretion reasonably. ${ }^{106}$ The appeal was dismissed.

The effect of the Court's dismissal of the appeal was to leave the receiver in charge of CSEI's interest in Block 5(c). While CSEI, under supervision of the monitor, retained possession and control of the remainder of its assets, the restructuring of CSEI's affairs under the CCAA had to proceed on the basis that no steps affecting Block 5(c) could be taken without the knowledge and co-operation of the receiver. This in turn meant that BG had a significant say in the restructuring of CSEI because BG was funding the receiver. BG therefore became a significant creditor of the receiver, while the receiver in turn became a significant creditor of CSEI for recovery of the funds borrowed by the receiver against the receiver's certificates, and secured by the receiver's borrowing charge.

A tortured and complex restructuring of CSEI and CEC followed the decision by the Court of Appeal, the particulars of which are not relevant to the issues discussed in this article. Through the sale of a 45 percent interest in Block 5(c), the merger of CSEI and CEC, and transfer of the operatorship to BG, CSEI was successfully restructured pursuant to a plan of arrangement which saw the receiver and all proved creditors paid in full. The said sale of a 45 percent interest was for an amount of US\$142,500,000, which translates into a total value of CSEI's 70 percent interest at the time (including any interest CEC may have had) of approximately US\$221,666,667.

The decisions by the Court of Queen's Bench and by the Court of Appeal to allow BG to appoint a receiver over CSEI's participating interest in Block 5(c) and appointing the receiver over CSEI's rights of operatorship remain contentious.

The JOA is a 62-page agreement (not including exhibits) that comprehensively governs the rights and obligations of the parties thereto. ${ }^{107}$ Amongst others, the JOA contains

BG International Limited v. Canadian Superior Energy, 2009 ABCA 127, 457 A.R. 38 [Canadian Superior (Interim Receiver)].

Ibid. at paras. 12-13.

Ibid. at para. 13.

Ibid. at para. 14 .

Ibid. at para. 19.

AIPN, Joint Operating Agreement Among Canadian Superior Energy Inc., Challenger Energy Corp., BG International Limited - Operating Agreement Covering: Block 5 C Trinidad and Tobago (11 August 2007), online: Deloitte \& Touche <http://www.deloitte.com/assets/Dcom-Canada/Local\%20 Assets/Documents/ca_Canadian_AffidavitEwenDenningFeb9Ex6_mar409.pdf>. 
extensive provisions governing the consequences of a default, the remedies on default, the removal of the operator, and dispute resolution. Upon default by a party, the non-defaulting party acquires some significant rights, while the defaulting party loses many of its rights. Amongst others, the defaulting party loses its right to attend operating committee meetings, may not transfer its participating interest except to non-defaulting parties, and has no right to receive its entitlement (which the JOA defines as a party's share of the production ${ }^{108}$ ). Where the defaulting party is the operator, all payments otherwise payable to the operator for the joint account costs shall be made to the notifying party instead, to be kept in a segregated account and applied to pay third party claims. The right to the defaulting party's entitlement vests in the non-defaulting parties who may sell such entitlement during the default period. Should the defaulting party fail to remedy all of its defaults within 30 days, a non-defaulting party has the right to require the defaulting party to completely withdraw from the JOA and the PSC. Once such notice is given, the defaulting party is deemed to have transferred its participating interest to the non-defaulting parties. In addition, at the expiry of the 30-day period, the non-defaulting parties are granted a mortgage and security interest in the defaulting party's participating interest and may enforce such rights by foreclosing upon them. The non-defaulting parties are entitled to become purchasers of the participating interest being foreclosed upon, and may credit against the purchase price what is owed to them by the defaulting party. ${ }^{109}$

The JOA allows for the removal of the operator, inter alia, in the event of the operator becoming insolvent or upon the operator being in material breach and remaining in breach for 30 days after receiving notice of default. Should the operator, however, dispute such breach and dispute resolution proceedings are commenced, the operator shall remain appointed but payments payable to the operator will be made to the notifying non-defaulting party on the basis set out above. ${ }^{110}$

The JOA provides for disputes to be resolved by negotiation, failing which they will be "exclusively and definitively resolved through final and binding arbitration, it being the intention of the Parties that this is a broad form arbitration agreement designed to encompass all possible disputes." "111 Any arbitration would be conducted in accordance with the rules of the London Court of International Arbitration, and the place of arbitration would be Calgary.

Notwithstanding the aforesaid provisions, the JOA expressly provides that any party may apply to a court for interim measures prior to the constitution of the arbitral tribunal or, "in the absence of the jurisdiction of the arbitral tribunal, in order to rule on interim measures in a given jurisdiction." 112 The arbitrators (or in an emergency the presiding arbitrator acting alone) are expressly given the power to grant interim measures, including injunctions, attachments, and conservation orders, which may immediately be enforced by Court order.

The JOA makes no express provision for the appointment of a receiver to take possession of a participating interest or to be substituted as operator. 
Having regard to the extensive remedies and powers the JOA gives to non-defaulting parties, one must reassess BG's allegation that the remedies under the JOA were insufficient to protect BG.

Had BG exercised its rights under the JOA and not applied for the appointment of the receiver, BG would have been entitled to the following relief:

(1) BG would have given Notice of Default under art. 8 and Notice of Removal as Operator under art. 4.10 (which BG did on 6 February 2009);

(2) CSEI would have been prohibited from transferring its participating interest to anyone other than BG;

(3) CSEI would have been prohibited from receiving its entitlement once production commenced;

(4) All payments otherwise payable to the operator for the joint account costs would have been paid to BG, to be kept by BG in a segregated account and applied to pay third party accounts;

(5) CSEI's rights to its entitlement would have vested in BG which would have been entitled to sell such entitlement during the default period had there been production;

(6) Had CSEI failed to remedy all its defaults within 30 days, BG would have had the right to require CSEI by notice to completely withdraw from the JOA and the PSC and, once such notice was given, CSEI would have been deemed to have transferred its participating interest to BG;

(7) At the expiry of the 30-day remedial period, BG would have been entitled to foreclose on its mortgage and secured interest and to sell CSEI's participating interest;

(8) BG would have been entitled to the immediate removal of CSEI as operator on the basis that CSEI was unable to pay its debts in the ordinary course as they became due and was therefore insolvent;

(9) BG would also have been entitled, after expiry of the 30-day remedial period, to CSEI's removal as operator. Had CSEI disputed that it was in material breach of the JOA (as it did), all payments payable to CSEI as operator would have had to be paid to BG as the non-defaulting party;

(10) BG would have been entitled to commence arbitration proceedings (as it did);

(11) BG would have been entitled to apply to the Court of Queen's Bench for interim measures (if any were needed) prior to the constitution of the arbitral tribunal. 
BG contended in the Court of Queen's Bench that the aforesaid rights and remedies were insufficient to protect BG, "especially given the financial challenges facing CSEI." 113 BG complained that an audit of the operator had found "that no joint account exists and funds have been commingled contrary to the JOA and Accounting Procedure," and alleged that, therefore, BG enjoyed no protection for the advancement of future cash calls by the operator. ${ }^{114}$ BG contended that the appointment of an interim receiver was the only way to protect BG "prior to it advancing further monies to ensure that the joint venture assets are protected." " $\mathrm{BG}$ said that there was extreme urgency to appoint an interim receiver because the drilling contractor had threatened to leave the Endeavour wellsite and that it would take a year to get a replacement rig in position. The appointment of an interim receiver, BG argued, would give BG comfort that its share of the outstanding costs of the Endeavour well would be used properly and to pay the drilling contractor. ${ }^{116}$ BG declared itself prepared to fund CSEI's share of the costs by way of a loan to the interim receiver under receiver certificates with a court ordered first priority charge. BG also declared itself prepared to provide an indemnity to the interim receiver, dependent however on the interim receiver retaining BG to assist in carrying out the interim receiver's obligations. BG proceeded to inform the Court of Queen's Bench that it was well qualified to assume the role of operator and was in a position to undertake such a role within five days. ${ }^{117}$

BG's reasons for requiring the appointment of the receiver casts some doubt on whether there was any real justification for such extraordinary and drastic relief. The JOA gave BG extensive protection against CSEI's default and its consequences. The relief and remedies provided by the JOA were designed to protect a non-defaulting party in the event that another party to the JOA encountered "financial challenges." The fact that CSEI as operator had commingled funds did not in any way detract from the immediate protection afforded to BG by the JOA, nor did it require the appointment of an interim receiver. It bears mention in passing that the subsequent CCAA proceedings and further audits by BG never uncovered any evidence that CSEI had misappropriated any joint account funds. BG was entitled, forthwith upon giving Notice of Default, to create a segregated account and to pay all joint account costs into such segregated account. BG would have been in sole control of the segregated account. Having given Notice of Default, BG became obliged under the express provisions of the JOA to satisfy the obligations of CSEI as the defaulting party. BG therefore had to fund the segregated account regardless of CSEI's financial woes. BG was entitled to use funds from the segregated account and immediately make payment to the drilling contractor, thereby removing the alleged threat to the joint assets. There was no need for the appointment of the receiver to ensure that the drilling contractor was paid, or to give BG comfort that its share of the joint account costs would be used properly. Contractually, BG already had all the tools to do so, and there was no suggestion that there was any impediment to BG exercising its right to create the segregated account and fund joint account expenses.

There was also no allegation by BG that CSEI was not technically qualified to be the operator. BG's complaint related to the commingling of funds and non-payment of the

113 Canadian Superior (Notice of Motion), supra note 86 (Evidence, 9 February 2009 affidavit of Ewen Denning) at 14, online: Deloitte \& Touche < http://www.deloitte.com/assets/Dcom-Canada/Local\%20 Assets/Documents/ca_canadian_affidavitewendenning_feb1909.pdf>.

Ibid.

Ibid.

Ibid.

Ibid. at 15-16. 
drilling contractor. No other reasons were advanced as to why, during the 30-day remedial period, it was necessary to immediately remove CSEI as operator. Had such reasons been advanced, it may have been appropriate for BG to seek its own appointment as the interim operator. Such an order would have been far less intrusive, disruptive, and damaging than the receivership order. BG's pre-condition to giving the receiver an indemnity, namely that it be retained to assist the receiver, in effect meant that BG immediately became the operator. Interposing the receiver as “operator” appears not to have been necessary.

Instead, BG should have exercised its rights under the JOA and pursued enforcement of its remedies in the arbitration. The appointment of the receiver, with the accompanying relief afforded by the receivership order, created rights for BG which it was not entitled to, and burdened CSEI with obligations it should not have had. It created a very expensive and intrusive receivership. By CSEI's estimates the eventual cost of the receivership was in the region of $\$ 3,500,000$, which amount represents the costs of the receiver, its legal advisors, and the costs of BG and its legal advisors - exclusive of any amounts paid to the receiver in respect of the joint operating costs.

The authors submit that the appointment of a receiver where a JOA covers the relationship between the parties, for the purposes in which BG sought such an appointment, is not appropriate and should not be encouraged. We argue that the appointment of the receiver by the Court of Queen's Bench in this case should not be used as a precedent for similar future appointments. Parties to a JOA should first exhaust their rights and comply with their obligations under the agreement before turning to the courts for interim relief.

The appointment of the receiver had far-reaching and dire consequences for CSEI:

(1) The immediate perception and reaction in the industry, particularly among CSEI's creditors, was that CSEI had been placed in full receivership. The subtlety that the receivership was limited to one of CSEI's assets, not all of them, escaped most people unfamiliar with the intricacies of insolvency law. The result was a "run on the bank.” A dispute under the JOA and even CSEI's removal as operator would likely not have been noticed beyond those parties immediately involved in Block 5(c). The granting of the receivership order, on the other hand, had devastating consequences and forced CSEI into filing for CCAA protection. CSEI was possessed of assets with a value significantly in excess of its debt when it made such filing. The joint CCAA and receivership cost totalled approximately $\$ 7,876,347$. Eventually, after eight months and CCAA protection, CSEI emerged with full payment to all its creditors, including the payment of interest;

(2) CSEI's rights of operatorship were effectively transferred to BG without CSEI being given any opportunity to exercise its contractual rights and without having an opportunity to present evidence in rebuttal;

(3) The receiver was given the power to sell CSEI's participating interest;

(4) The receiver's charge was created and given priority ahead of whatever existing rights CSEI's other creditors may have had; 
(5) A \$14 million fixed and specific charge in favour of CWB was created against CSEI's participating interest, a charge that CWB previously did not have;

(6) The receiver's borrowing charge of up to $\$ 47$ million (subsequently increased to \$52 million) was created, which effectively created security for all joint account costs that BG had to pay and improved BG's rights to security and enforcement under the JOA; and

(7) The receiver's expenses became a joint account liability, something that is not contemplated or authorized by the JOA.

The Court of Queen's Bench heard the receivership application on very short notice, and was faced with the situation where BG made very serious allegations against CSEI, including irreparable harm should an interim receiver not be appointed. The Court did not have the luxury of time and did not have the benefit of a full presentation by CSEI of all the relevant facts. The Court was convinced by BG that the appointment of the receiver was the only way by which to avoid irreparable harm to BG. A Justice in Chambers often has to make these difficult decisions without an opportunity for all the evidence and arguments to be properly aired. It is easy to criticize a decision granted by a court after the event. That is not the authors' intent. Rather, our caution is that the appointment of the receiver in this case should not be elevated to a precedent. The appointment was effectively made on an ex parte basis, was intended as an interim measure, and can be shown ex post facto not to have been justified.

The decision by the Court of Appeal should not be regarded as an approval of the use of a receivership under the present circumstances. By the time the Court heard the appeal, the train had left the station, so to speak. BG was effectively the operator, CSEI had been forced into CCAA, and to undo the consequences of the receivership order was a futile exercise. The Court did not undertake a detailed analysis of the rights and obligations of the parties under the JOA. The decision of the Court of Appeal was driven by practical considerations and by its realization that the chambers judge "had to make a difficult decision in a very short period of time based on limited materials."

The Court stated in its reasons that the appointment of a receiver "should not be lightly granted" and, if possible, a remedy "short of a receivership" should be used. ${ }^{119}$ The appointment of a receiver must be "just or convenient." 120 The powers granted to an interim receiver must be limited to those powers strictly required by the interim receiver to accomplish the purpose of its appointment, and no more. ${ }^{121}$ Here BG had effective and immediate remedies under the JOA. There was no need for the appointment of the receiver and if BG required protection beyond the rights afforded to it under the JOA, remedies short of receivership, such as appointing BG as the interim operator, would have been more appropriate. 
By way of conclusion, we caution parties to JOAs not to seek, as a matter of course, the appointment of interim receivers in the event of disputes between the parties to such an agreement. Such appointments must be reserved for those rare occasions where a nondefaulting party will indeed suffer irreparable harm despite exercising all of its available contractual rights.

\section{THE BROOKFIELd PRIORITY DISPUTE}

The decision by the Alberta Court of Queen's Bench in Brookfield ${ }^{122}$ briefly caused considerable concern to the secured lenders of oil and gas well operators. The status quo ante, however, was restored by the Alberta Court of Appeal some ten months later. ${ }^{123}$

Vanquish Oil and Gas Corporation (Vanquish) was the operator of the Simonette well. Karl Oil and Gas Ltd. (Karl) and Buffalo Resources Corporation (Buffalo) made conflicting claims to a 45 percent working interest in the Simonette well. Brookfield Bridge Lending Fund Inc. (Brookfield) was the secured lender of Vanquish.

Vanquish, as operator, was required to remit 45 percent of the net production revenues of the Simonette well to the owner of the 45 percent interest, which was the subject of the dispute between Karl and Buffalo. That dispute was not relevant to the priority dispute between Brookfield and the working interest owner in the decisions under discussion because Karl and Buffalo took a common position before the Court.

All revenues received from the Simonette well were deposited by Vanquish into its general bank account at TD Canada Trust. The commingling of the revenues with Vanquish's own funds was permitted by the 1990 Canadian Association of Petroleum Landmen (CAPL) Operating Procedure, which also deemed such revenue to be trust monies. ${ }^{124}$

On 28 March 2007, Vanquish was placed in receivership pursuant to an application by Brookfield. At the date of receivership Vanquish was in default of remitting production revenue to the working interest owner in an amount agreed by the parties to be approximately \$320,539. The lowest balance the general account reached was \$40,281 on 14 March 2007. On 16 March 2007, a further \$40,599 of revenue relating to the Simonette well was deposited. ${ }^{125}$ Further deposits not impressed with the trust were also made. On the date of receivership the balance in the account was $\$ 417,913$.

The receiver sold all the assets of Vanquish. The amount of \$320,539 was agreed to stand as a reserve in the place of the assets of Vanquish pending a decision on the claim by the working interest owner that it had a priority claim to such funds.

The trial judge concluded that the working interest owner had a claim in trust to the assets of Vanquish (or the proceeds thereof) to the extent of its unpaid net production revenues. This conclusion was arrived at by the trial judge finding that Vanquish breached the fiduciary duty it owed as trustee to the working interest owner, which in turn entitled the working 
interest owner to a constructive trust over all of Vanquish's property such that the proceeds subsequently realized from the sale of such assets by the receiver were impressed with a constructive trust in favour of the working interest owner. ${ }^{126}$ Having found therefore that the working interest owner had a proprietary claim to the proceeds, the trial judge then resolved the priority dispute between the working interest owner and Brookfield in favour of the working interest owner. That conclusion was reached on the basis that both parties were innocent third parties but that Brookfield, as the secured lender, was in a "far better position to ensure that its customer conducted its affairs in a fashion so as to honour the obligations clearly imposed upon it."127

The impact and effect of the trial judge's decision was to impose the burden of a breach of trust by an operator on its secured lender. Needless to say, the decision was not well received by lending institutions, and Brookfield promptly filed an appeal.

The decision was reversed on appeal. The Court of Appeal found that Vanquish was clearly in breach of trust by expending the trust funds in an unauthorized manner, and was therefore in breach of its fiduciary duties as trustee. ${ }^{128}$ The Court, however, referred to the bona fide third party rule, the effect of which is that much of the risk of a breach of trust by a trustee will fall on the beneficiaries. The Court also stated that the courts will decline to impose a constructive trust where doing so would prejudice the interests of bona fide third parties. ${ }^{129}$

The Court of Appeal held that the express trust created by the 1990 Procedure only extended to the amounts of $\$ 40,218$ (the remaining balance in the general account at its lowest point) and \$40,599 (the additional trust monies deposited and never expended). ${ }^{130}$

The Court disagreed that the working interest owner had proved the existence of a constructive trust. The Court referred to Soulos v. Korkontzilas, ${ }^{131}$ in which four conditions were identified to be necessary before a constructive trust based on wrongful conduct can be imposed by a court. Those conditions, summarized, are as follows:

(1) The operator must have an equitable obligation;

(2) The assets held by the operator must result from the operator's agency activities in breach of the equitable obligation;

(3) The owner must show a legitimate reason for seeking a proprietary trust remedy;

(4) There must be no factors rendering the imposition of a constructive trust unjust. For example, the interests of intervening bona fide creditors must be guarded. ${ }^{132}$

Ibid. at paras. 38, 53-55.

Ibid. at para. 53.

Brookfield (C.A.), supra note 2 at para. 11.

Ibid. at paras. 10,13 .

Ibid. at para. 13.

[1997] 2 S.C.R. 217 [Soulos].

Ibid. at para. 45 . 
The Court of Appeal found that the second and fourth preconditions for a constructive trust were not proven. ${ }^{133}$ The second precondition was absent because there was no satisfactory evidence of "what, if any, specific assets Vanquish purchased with trust funds." 134 There was no proof "that the trust proceeds were expended on any of Vanquish's assets that formed part of the eventual realization by the receiver." ${ }^{135}$ Vanquish's wrongdoing could not be traced into any asset, which precluded the imposition of a constructive trust. ${ }^{136}$ The fourth precondition was missing because a secured creditor does not have the positive duty imposed by the trial judge on Brookfield "to monitor the fiduciary activities of its borrower." 137 The Court disagreed with the trial judge's analysis because it discounted "the fact that the underlying risk of misappropriation was created by the [working interest owner] allowing the commingling of the trust funds, and transfers the duty of monitoring that risk to [Brookfield]."138 That approach, the Court of Appeal found, was contrary to the principle that "the interests of intervening creditors must be protected." 139

The Court disagreed that Brookfield was in a better position to prevent breaches of trust. Imposing such a duty on the secured lender would require it to monitor the operator's business on a daily basis to know which funds were trust funds. It would be unreasonable to impose such a duty. ${ }^{140}$ The imposition of a constructive trust would also be unjust to the unsecured creditors which had no "better opportunity" to prevent the breach of trust. ${ }^{141}$

The Court therefore held that "it was an error of principle to impose a constructive trust in the circumstances." 142 The express trust only attached to the lowest balance of the account on 14 March 2007, and to the working interest owner's portion of the additional trust funds deposited on 16 March 2007.

The decision by the Court of Appeal cannot, in our submission, be faulted. It is a fair and just result, placing the risk of wrongdoing by the trustee on the innocent party who participated in the creation of such risk. The decision is also the more sensible commercial outcome. Had the decision of the trial judge been confirmed, the impact of imposing a monitoring duty on secured lenders over operators would have been far-reaching. The likely result would have been a refusal by lenders to advance loans to operators unless separate trust accounts were opened, and the commingling of funds would have been prohibited. Secured lenders would have imposed a monitoring system to ensure that funds were not being commingled and the oil and gas industry would have been required to fund the expense of such a system. The cost of loans would have increased and profit margins of oil and gas property owners would have decreased. Working interest owners in turn would have enjoyed an unfair priority in insolvencies over secured lenders and unsecured creditors. This case illustrates the dangers and pitfalls of the practice, sanctioned by the CAPL Procedures, of allowing operators to commingle trust funds with non-trust funds. It is a practice that

Brookfield (C.A.), supra note 2 at para. 18.

Ibid. at para. 19.

Ibid. at para. 20.

Ibid., citing Bassano Growers Ltd. v. Diamond S. Produce Ltd. (Trustee of), 1998 ABCA 198, 216 A.R.

328 at para. 13.

Brookfield (C.A.), ibid. at para. 21.

Ibid.

Soulos, supra note 131 at para. 45 , cited in ibid.

Brookfield (C.A.), ibid. at para. 22.

Ibid. at para. 23.

Ibid. at para. 26. 
regularly results in significant losses to working interest owners and is the origin of complex disputes as illustrated by the set-off dispute referred to above between Trilogy and SemCAMS.

The origin of the practice of allowing commingling and the reasons for continuing such practice fall outside the scope of this article. Suffice it to say that the time to review and reconsider that practice may be overdue.

\section{ConCLUSiON}

The effects of the latest recession undeniably led or contributed to the insolvencies of several energy companies in Alberta, as well as across the border. The judicial decisions from Alberta that the authors analyze above serve to effectively highlight the application of the principles of contract law, security, and set-off as they apply in the special circumstances of both insolvency proceedings and the specialized nature of the oil and gas industry.

Even where the applicability of well-known legal principles to the oil and gas industry in the context of insolvency proceedings appear relatively straightforward, as it often did in the SemCanada Group restructuring, open issues still remain that the authors have attempted to bring to light. From those cases it can be seen that the potential exists for further arguments regarding priorities, distributions, and set-off in future insolvencies of a major group of oil and gas companies.

Controversy can often be the result of the collision of insolvency principles with the practical day-to-day realties of an oil and gas producer. Nowhere is this more evident than in the CSEI interim receivership/restructuring. The dual procedures that resulted in the CSEI insolvency exemplify not only the fast pace at which oil and gas insolvencies are often compelled to proceed, but also the complexities that can arise out of the necessity for creditors to move quickly to protect oil and gas assets.

Finally, the Brookfield priority dispute illustrates the complicated interaction between operators, working interest participants, and secured creditors, which, even absent an insolvency, is often difficult to navigate. When an underlying insolvency of an operator is added, it can be quite challenging for a court to sort through the rights and obligations of all these parties, leading to rounds of litigation in addition to appeals, as it did in that case. 